\title{
The Attitude and Behavior Related to Social Distancing as Prevention Transmission of Coronavirus Disease 19 among Adolescents Living in Coastal Area of Indonesia
}

\author{
Eko Mulyadi* (D), Abd Wahid $(\mathbb{D}$, Arif Rahman Hakim (D) \\ Department of Nursing, Faculty of Health Science, University of Wiraraja, Sumenep, Indonesia
}

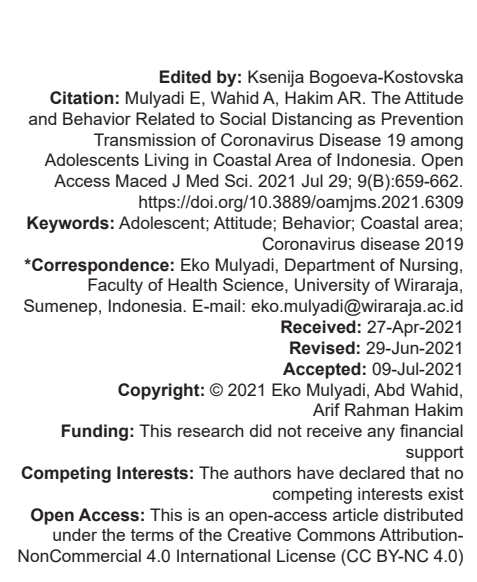

Introduction

The incidence of coronavirus disease 2019 (COVID-19) in Indonesia has increased rapidly [1], [2], [3]. The Indonesian government has compiled certain good preparedness and a response plan based on the $\mathrm{WHO}$ recommendations in facing COVID-19, such as practicing social distancing. Social distancing was identified as a primary strategy to prevent Coronavirus transmission [4], [5], [6]. On the other hand, the rate of COVID-19 infection remains high, indicating that the mitigations and strategic action again COVID19 were not well-implemented. The data retrieved in November 2020 showed a total of 444,348 infections and 14,761 deaths nationally. At the same time, East Java became one of the top two provinces of COVID-19 infection rate with a reported 54,865 cases [7].

Promoting physical or social distancing in East Java, especially among the coastal community, has serious challenges because they hold gathering habits derived from Islamic and hereditary culture [8], [9]. The majority of the coastal community is Muslim, particularly in
Madura [10]. Indeed, their habitual activities are influenced by Islam instruction such as a handshake, worship activities, and certain religious events conducted in the congregation. Although Islam has rules for maintaining cleanliness and implementing activities that can prevent infectious diseases, it is often neglected because activities carried out together have become a permanent habit that is difficult to control. Furthermore, most people are unwilling to pay the costs of social distancing. Most Indonesians disobeyed the social distancing policy by still doing activities outside the home such as having a vacation and traveling to other cities [11]. These phenomena would limit the effectiveness of social distancing [12].

Adolescents constitute the school-age group that spends a large proportion of their day in school or pursuing school-related activities [13]. The adolescents are well-educated people who surely have enough knowledge about social distancing as an effort against COVID-19 infection, including those who live in a coastal area. However, the rapid increase of infection in East Java indicates that the attitude and behavior of adolescents toward social distancing are in question. To implement health protocols such as social distancing, 
they should be able to change their habit of performing worship or other activities conducted in a congregation.

The study of attitude and behavior related to health and prevention of infectious disease is important. A simulation study on agent-based influenza showed that small changes in behavior could have a significant effect on transmission patterns during epidemics [14]. Therefore, this study aimed to explore the attitude and behavior of coastal adolescents toward social distancing in response to prevent COVID-19 transmission.

\section{Methods}

The design of the study is cross-sectional, with Madura, East Java, Indonesia. The permission to conduct this study was received from the Institutional Review Board of a university (Approval No. No.1057/UN25.8/ KEPK/DL/2020). Before participating in the study, the subjects were informed of the purpose of the research and were assured of their right to refuse to participate in the study or withdraw their consent at any stage.

The data were collected through an online questionnaire shared using social media from March to August 2020. The instruments used in this study are attitude to social distancing and behavior of social distancing. The questionnaires were purposed as a self-managed questionnaire according to the standard protocols for the questionnaire design and testing. The overall fields, concerns, and response options in the questionnaires were related to social distancing. The questionnaire of attitude to social distancing consists of 10 items with a Likert scale format ranging from 5 (strongly disagree) to 1 (strongly agree). The total score was used which categorized attitude into a positive attitude (score $>50$ ) and negative attitude (score $\leq 50$ ). The behavior of social distancing questionnaire consists of ten items with a dichotomous scale format (yes/no). The total score was applied which categorized behavior as good (score $\geq 7$ ), sufficient (score 3-6), and insufficient $(\leq 2)$. The content validity index for scale are 0.80 and 0.90 for questionnaire attitude and behavior, respectively, in which they are an acceptable score [15]. The Cronbach's alphas are 0.873 and 0.865 for questionnaire of attitude and behavior in each that reach good level [16]. The correlation among variables was analyzed using Pearson's Chi-square test.

\section{Results}

\section{Sociodemographic of participants}

A total of 224 participants was recruited in this study. All the participants (100\%) were Muslim. The 224 adolescent participants living in the coastal area of

majority $(45 \%)$ of participants were aged $15-18$ years. Of these, $156(70 \%)$ were males and the remaining $68(30 \%)$ were female. Regarding the education level of participants, 24 (10.7\%) were junior high school, 167 (74\%) were senior high school, and 33 (14.7\%) were university students.

\section{Attitude and behavior of participants related to social distancing}

The majority of participants have a good attitude or agreed to perform social distancing as prevention of COVID-19 infection. The participants mostly agreed to do the daily activities at home. However, praying from home, wearing a mask, and not organizing mass gathering events was still a challenge (Table 1).

Table 1: The attitude of participants related to social distancing

\begin{tabular}{|c|c|c|c|c|c|c|c|c|}
\hline \multirow[t]{2}{*}{ Attitude } & \multicolumn{2}{|c|}{$\begin{array}{l}4 \text { Strongly } \\
\text { disagree }\end{array}$} & \multicolumn{2}{|c|}{3 Disagree } & \multicolumn{2}{|c|}{2 Agree } & \multicolumn{2}{|c|}{$\begin{array}{l}1 \text { Strongly } \\
\text { agree }\end{array}$} \\
\hline & $\mathrm{n}$ & $\%$ & $\mathrm{n}$ & $\%$ & $\mathrm{n}$ & $\%$ & $\mathrm{n}$ & $\%$ \\
\hline Physical distancing/social distancing & 1 & 0 & 1 & 0 & 35 & 16 & 187 & 83 \\
\hline Not organizing mass gathering events & 14 & 6 & 7 & 3 & 29 & 13 & 174 & 78 \\
\hline Wearing a mask & 8 & 4 & 25 & 11 & 67 & 30 & 124 & 55 \\
\hline Work from home & 1 & 0 & 16 & 7 & 49 & 22 & 158 & 71 \\
\hline Study from home & 6 & 3 & 12 & 5 & 46 & 21 & 160 & 71 \\
\hline Worship/pray from home & 15 & 7 & 32 & 14 & 61 & 27 & 116 & 52 \\
\hline $\begin{array}{l}\text { Prohibit family from going outside the } \\
\text { house if in sick/fever condition }\end{array}$ & 6 & 3 & 5 & 2 & 35 & 16 & 178 & 79 \\
\hline Keeping children at home & 2 & 1 & 0 & 0 & 31 & 14 & 191 & 85 \\
\hline Regular exercise & 3 & 1 & 1 & 0 & 33 & 15 & 187 & 83 \\
\hline Think positively and do leisure & 3 & 1 & 3 & 1 & 34 & 15 & 184 & 82 \\
\hline
\end{tabular}

As shown in Table 2, generally the participants have good behavior related to social distancing as prevention of COVID-19 infection. However, there is still a negative behavior on a certain issue in which almost half of the participants are reluctant to help isolating people with positive COVID. This may be due to the public fear of being infected by coronavirus disease.

Table 2: The behavior of participants related to social distancing

\begin{tabular}{|c|c|c|c|c|}
\hline \multirow[t]{2}{*}{ Behavior } & \multicolumn{2}{|l|}{ No } & \multicolumn{2}{|l|}{ Yes } \\
\hline & $\mathrm{n}$ & $\%$ & $\mathrm{n}$ & $\%$ \\
\hline Wash hands with water using soap or hand sanitizer & 2 & 1 & 222 & 99 \\
\hline Avoid touching the face, mouth, nose & 55 & 25 & 169 & 75 \\
\hline $\begin{array}{l}\text { Cover mouth with upper arm or tissue when sneezing or } \\
\text { coughing or using a mask }\end{array}$ & 14 & 6 & 210 & 94 \\
\hline Wear a mask if you have respiratory problems & 27 & 12 & 197 & 88 \\
\hline Keep a minimum distance of 1 meter from others & 43 & 19 & 181 & 81 \\
\hline Clean the environment with antiseptic and disinfectant & 67 & 30 & 157 & 70 \\
\hline $\begin{array}{l}\text { Report to the doctor or health worker if there are family } \\
\text { members who experience symptoms of fever, cough, } \\
\text { shortness of breath, or recently visited by a COVID- } 19 \text { sufferer }\end{array}$ & 36 & 16 & 188 & 84 \\
\hline $\begin{array}{l}\text { Isolate yourself if you experience symptoms of fever, cough, } \\
\text { shortness of breath and just met with a positive confirmation of } \\
\text { COVID-19 }\end{array}$ & 9 & 4 & 215 & 96 \\
\hline $\begin{array}{l}\text { Encourage family and others not to leave the house if there is } \\
\text { no urgent need }\end{array}$ & 5 & 2 & 219 & 98 \\
\hline Isolate people who are corona positive & 87 & 39 & 137 & 61 \\
\hline
\end{tabular}

The result of Pearson's Chi-square test $(p=0.019)$ showed that attitude has a significant relationship with behavior related to social distancing as a prevention of COVID-19 infection (Table 3).

Table 3: Correlation between attitude and behavior related to social distancing

\begin{tabular}{|c|c|c|c|c|c|c|c|c|c|}
\hline \multirow[t]{3}{*}{ Attitude } & \multicolumn{6}{|c|}{ Behavior } & \multirow{2}{*}{\multicolumn{2}{|c|}{ Total }} & \multirow[t]{3}{*}{$p$-value } \\
\hline & \multicolumn{2}{|c|}{ Insufficient } & \multicolumn{2}{|c|}{ Sufficient } & \multicolumn{2}{|c|}{ Good } & & & \\
\hline & $\mathrm{n}$ & $\%$ & $\mathrm{n}$ & $\%$ & $\mathrm{n}$ & $\%$ & $\mathrm{n}$ & $\%$ & \\
\hline Negative & 1 & 1 & 16 & 15 & 93 & 85 & 110 & 100 & 0.019 \\
\hline Positive & 0 & 0 & 5 & 4 & 109 & 96 & 114 & 100 & \\
\hline
\end{tabular}




\section{Discussion}

The attitude of coastal adolescents toward social distancing as prevention of COVID-19 infection was not entirely good. Specifically, they did not agree to perform worship at home. As an Indonesian Muslim, performing worship together has become a habit that is hard to break. Islam has encouraged adherents to pray and perform any worship together at a mosque.

Islam has significantly influenced every cultural component in coastal society. The majority of community activities emerged based on Islamic reference. The habit of carrying out gathering activities does not only occur in religious activities, it also spreads to other cultural activities such as weddings, music, and art exhibitions. Therefore, implementing the health protocol for not holding or attending mass activities is difficult to obey.

Wearing a mask is also tough to do among coastal adolescents. Similar to a previous study, a number of people were also reluctant to wear a mask [17]. The adolescents might not be accustomed to using masks that can restrict breathing. Further, wearing a mask can also reduce the quality of communication because they have to use a louder voice and cannot share a smile.

A number of adolescents are averse to help and encourage infected people to do self-isolation. They do not approach the infected people because they are fearful to be infected by COVID-19. This finding shows that they actually have awareness about the dangers of COVID-19 by staying away from infected people, but they still find it difficult to stop their habit of gathering, especially in worship activities. On the other hand, the fear of being infected with COVID-19 is even experienced by health workers. A previous study reported that almost a half of the health professionals were reluctant to provide services even to those individuals who were asymptomatic and not confirmed cases [18]. The possible reason is that they might receive insufficient information and knowledge about COVID-19 transmission and its prevention so that they overreact toward infected people. Furthermore, the stress associated with the outbreak and the feeling of being at risk of contracting might have impacted their attitude related to COVID-19 [19].

The result of this study shows that attitude and behavior about social distancing are significantly correlated. Attitudes assumed to reflect predispositions to behave in a particular manner are believed to be integrally related to most aspects of social life, carrying expectations about human behavior [20]. Attitudes were reported to have some utility in predicting behavior [21]. Thus, improving a positive behavior related to social distancing through attitude is recommended.

\section{Conclusion}

In general, the coastal adolescents have a good attitude and behavior related to social distancing as a prevention of COVID-19 infection. Several issues, such as performing worship together, organizing, and attending a mass activity might be influenced by culture and Islamic reference. The socialization of COVID prevention needs to involve a religious approach. Still, the reluctance to wearing a mask and poor behavior to help infected people to do self-isolation may depend on adolescents' knowledge and beliefs regarding the COVID-19 pandemic. Massive delivery of information and effort related to COVID-19 prevention is demanded.

\section{Limitation}

This research was conducted for adolescents. Further study needs to explore the attitude and behavior related to social distancing for other age groups. Furthermore, this research only investigated two elements (attitude and behavior) of the Theory of Planned Behavior; future researches are suggested to include more variables.

\section{References}

1. Megatsari $H$, Laksono $A D$, Ibad M, Herwanto $Y T$, Sarweni KP, Geno RA, et al. The community psychosocial burden during the COVID-19 pandemic in Indonesia. Heliyon. 2020;6(10):e05136. https://doi.org/10.1016/j.heliyon.2020.e05136

PMid:33020744

2. Nursalam N, Sukartini T, Priyantini D, Mafula D, Efendi F. Risk factors for psychological impact and social stigma among people facing Covid-19: A systematic review. Syst Rev Pharmacy Medknow Publ. 2020;11(6):1022-8.

3. Setiawati $Y$, Wahyuhadi J, Joestandari F, Maramis MM, Atika A Anxiety and resilience of healthcare workers during COVID-19 pandemic in Indonesia. J Multidiscip Healthc. 2021;14:1. https:// doi.org/10.2147/jmdh.s276655

PMid:33442258

4. Khan MA, Atangana A, Alzahrani E. The dynamics of COVID-19 with quarantined and isolation. Adv Differ Equations. 2020;2020(1):1-22. https://doi.org/10.1186/ s13662-020-02882-9 PMid:32834821

5. Lewnard JA, Lo NC. Scientific and ethical basis for socialdistancing interventions against COVID-19. Lancet Infect Dis. 2020;20(6):631-3. https://doi.org/10.1016/ s1473-3099(20)30190-0

PMid:32213329

6. Rachman BE, Rusli M, Miftahussurur M. The hidden vulnerability of COVID-19 observed from asymptomatic cases in Indonesia. Syst Rev Pharm. 2020;11(2):703-13.

7. Ministry of Health of the Republic of Indonesia, the distribution of covid-19 in Indonesia: 2021. Avaliable from https://covid19. go.id/peta-sebaran. [Last accessed 2020 Feb 02]. 
8. Rakotoarisoa FM, Praptapa A, Suyono E, Usuman I. Factors influencing preventive intention behavior towards COVID-19 in Indonesia. J Behav Sci. 2021;16(1):14-27.

9. Yanti B, Wahyudi E, Wahiduddin W, Novika RG, Arina YM, Martani NS, et al. Community knowledge, attitudes, and behavior towards social distancing policy as prevention transmission of COVID-19 in Indonesia. J Adm Kesehat Indones. 2020;8(2):414. https://doi.org/10.20473/jaki.v8i2.2020.4-14

10. Calipel S, Lucas-Polomeni M, Wodey E, Ecoffey C. Premedication in children: Hypnosis versus midazolam. Pediatr Anesth. 2005;15(4):275-81. https://doi. org/10.1111/j.1460-9592.2004.01514.x

PMid: 15787917

11. Saifulloh M. Early Homecoming Desire in the Middle of the Corona Pandemic, 2020. Avaliable from https://www.okezone.com/. [Last accessed 2021 Mar 27].

12. Reluga TC. Game theory of social distancing in response to an epidemic. PLoS Comput Biol. 2010;6(5):e1000793. https://doi. org/10.1371/journal.pcbi.1000793 PMid:20523740

13. Marin $P$, Brown $B$. The school environment and adolescent wellbeing: Beyond academics. JAMA. 2008;295(13):1549-55.

14. Pawelek KA, Salmeron C, Del Valle S. Connecting within and between-hosts dynamics in the influenza infection-staged epidemiological models with behavior change. J Coupled Syst multiscale Dyn. 2015;3(3):233-43. https://doi.org/10.1166/ jcsmd.2015.1082

PMid:29075652

15. Polit DF, Beck CT. The content validity index: Are you sure you know what's being reported? Critique and recommendations. Res Nurs Health. 2006;29(5):489-97. https://doi.org/10.1002/nur.20147
PMid:16977646

16. Cronbach LJ, Schönemann P, McKie D. Alpha coefficients for stratified-parallel tests. Educ Psychol Meas. 1965;25(2):291312. https://doi.org/10.1177/001316446502500201

17. Ferdous MZ, Islam MS, Sikder MT, Mosaddek AS, ZegarraValdivia JA, Gozal D. Knowledge, attitude, and practice regarding COVID-19 outbreak in Bangladesh: An online-based cross-sectional study. PLoS One. 2020;15(10):e0239254. https://doi.org/10.1371/journal.pone.0239254

PMid:33035219

18. Gunjawate DR, Ravi R, Yerraguntla K, Rajashekhar B, Verma A. Impact of coronavirus disease 2019 on professional practices of audiologists and speech-language pathologists in India: A knowledge, attitude and practices survey. Clin Epidemiol Glob Health. 2021;9:110-5. https://doi.org/10.1016/j. cegh.2020.07.009

PMid:32838065

19. World Health Organization. Report of the WHO-China Joint Mission on Coronavirus Disease 2019 (COVID-19). Geneva: World Health Organization; 2020. Available from: https:// www.who.int/publications/i/item/report-of-the-who-china-jointmission-on-coronavirus-disease-2019-(covid-19).https://doi.org/ 10.3410/f.737509210.793572110. [Last accessed 2021 Feb 24].

20. Mansor R, Tingi-Sheau L. The Psychological Determinants of Energy Saving Behavior. IOP Conference Series: Materials Science and Engineering; 2019. Available from: https://www. iopscience.iop.org/article/10.1088/1757-899X/620/1/012006/ meta. https://doi.org/10.1088/1757-899x/620/1/012006. [Last accessed 2021 Mar 21].

21. Chaiklin H. Attitudes, behavior, and social practice. J Sociol Soc Welf. 2011;38:31. 